The New Review of Information Networking, 3, 1997, 185- 201 [ISSN 1361-4576]

\title{
SLISNET - UNESCO's experiment in virtual networking between Schools of Librarianship and Information Sciences
}

\author{
Ian M. Johnson
}

School of Information and Media, The Robert Gordon University, Aberdeen AB24 5BN

(i.m.johnson@rgu.ac.uk)

\begin{abstract}
This paper examines the origins and activities of SLISNET - an international network of Schools of Librarianship and Information Sciences, established by UNESCO in 1995 as an experiment in collaboration across the Internet. SLISNET has a Web site, a discussion list, and members committed to various other activities to develop teaching and research related to the electronic library environment. The paper puts the aims and activities of the network in the broader context of collaboration between Schools, and international technical cooperation programmes. Using the aims of these activities, it reviews SLISNET's progress to date, and proposes some suggestions for future development.
\end{abstract}

\section{Introduction}

The rapid growth of the Internet over the last two or three years appears to present new opportunities for communication. Much has been made of the challenges and opportunities this presents for practitioners, but little attention has been given to the development of the educators in the information field. This paper describes the establishment of a virtual network, established by UNESCO as an experiment to try to take advantage of this new medium to encourage collaborative developments between Schools of Librarianship and Information Sciences. It sets the network in the context of traditional approaches to international technical cooperation programmes between Schools, reviews progress to date, and discusses suggestions for future development. However, the views expressed in this paper are solely those of the author, and should not be considered to be those of UNESCO or of the other members of SLISNET.

\section{Cooperation between Schools of Librarianship}

Schools of Librarianship and Information Sciences face major challenges at the moment, as the pace of change in their professional and institutional environments quickens. The emergence of the 'Information Society' presents a unique opportunity to assert a new position both in the academic world and more significantly in the society served by libraries and information services. No longer should the information professional be seen in a subservient role. The era of the 'Knowledge Manager' has arrived. ${ }^{i}$ However, to be well equipped to seize the emerging opportunities, the information profession needs new knowledge, skills and attitudes, ${ }^{\text {ii }}$ not least to be fully familiar with the new Information and Communication 
Technologies, and competent to navigate through the vast range of information now available through the Internet.

The introspective focus on libraries as institutions is giving way to the concept of the virtual library, the library without walls ${ }^{\mathrm{iii}}$, and information specialists are being confronted with the need to organise and exploit knowledge communicated and stored in non-traditional means. The challenge of developing professionals with these skills rests largely on the Schools of Librarianship and Information Sciences. However, it is debatable whether the Schools are sufficiently closely involved in these developments, even in the industrialised countries. Much of the initiative has been seized by those practitioners who have taken up the major grants available for developing large scale demonstrators, and who are thus leading the implementation of new systems. Although some Schools have been developing relevant new teaching programmes, in many respects they been marginalised, particularly in research and development activities, at a time when it is crucial that they should transmit not only a new body of knowledge and skills to the emerging generation of professionals but also an enthusiasm for new approaches. ${ }^{\text {iv }}$ However, if the educators are to successfully develop the professional knowledge base, and convey the significance of this new environment to their students to make them assured practitioners, the educators themselves need to experience the potential of the new media.

Most of the Schools are small, and have few staff specialising in the same subject field. To exchange ideas about new teaching methods and research interests, academics must usually rely on contact with colleagues in other Schools. These opportunities are limited. Although some countries support several Schools, opportunities for teachers to get away from the classroom can be limited by heavy teaching loads, and in some cases geography and the cost of travel imposes other barriers. Nonetheless, in those countries where several Schools coexist, professional groupings have been established to support cooperative activities, such as ALISE in the U.S.A., BAILER in Great Britain ${ }^{\mathrm{v}}$, and ABEBI in Brazil.

Regional conferences such as the regular meeting of the Scandinavian Schools ${ }^{\mathrm{vi}}$ and groupings such as EUCLID: the European Association for Information and Library Education and Research ${ }^{\text {vii }}$ have also been established, because the need to change and develop is universal. In almost all countries, attempts being made to revise curricula to update the applications of Information Technology in appropriate parts of courses. However, most Schools are currently operating in state education systems in which adequate levels of funding are not available for economic or ideological reasons. This affects the ability to implement change, through limitations on the development of not only equipment and library facilities, but also the knowledge and skills of the teaching staff. These financial constraints inhibit participation in activities sponsored by regional groupings even more than national activities.

\section{International technical cooperation projects}

Schools in the developing countries are doubly handicapped. Not only are they usually isolated from contact with other Schools, they are also isolated from the Continuing Professional Development programmes which are well established for the practitioner community in the developed countries. Participation in an international technical cooperation programme can provide a means of overcoming these problems, but this solution tends to bring only short term benefits because the funding agency's support is usually for a fixed duration. 
International technical cooperation programmes have traditionally relied heavily on the exchange of staff to transfer information and ideas about current practice, sometimes supplemented by the provision of teaching materials. Their aims are generally:

- planning and developing modern curricula

- implementing new teaching methods

- improving learning resources

- establishing closer contact for both staff and students with all aspects of professional practice and professional education in the partner country

- creating partnerships for future collaborative developments. viii

Projects to support the development of Schools of Librarianship and Information Sciences have featured in the international assistance programmes of the national governments of most of the industrialised countries ${ }^{\mathrm{ix}}$, as well as in the work of UNESCO, the European Commission, and other international governmental agencies. Whilst the importance of information to corporate development is receiving increasing attention in the developed countries $^{\mathrm{x}}$, recent attempts to raise the profile of information development by investigating whether there is a causal relationship between it and economic development in the 'Third World' have been inconclusive. ${ }^{\mathrm{xi}}$, xii

Regrettably, relatively few Schools have been involved in international technical cooperation programmes, participation in which can brings mutual benefits. For the less developed institution, the benefits are usually tangible and obvious. For the better developed partner, the benefits are less tangible and less obvious, but nonetheless significant in terms of individual staff development and enhanced institutional profile. ${ }^{\text {xii }}$ The barriers to participation appear to lie partly in the attitudes within Schools which have little prior involvement - and which lack confidence that the benefits will outweigh the demands on their time and resources. The major problem lies, however, in the limited funding available. Fiscal policies of the governments of the industrialised countries in recent years have been less supportive of international technical cooperation activities, and support for the development of library and information services - and professional educational institutions - appears to have been reduced at least proportionately. The reduction of financial support for established forms of worthwhile activity always focuses attention on alternative, less costly means of achieving similar objectives. For some years there have been predictions that alternative communications media would become a financially viable substitute for meetings which would otherwise incur travel costs. ${ }^{\text {xiv }}$ Could communication through the Internet become an effective substitute for the exchange of people which has conventionally been a significant element in international technical cooperation programmes?

\section{The origins of SLISNET}

UNESCO established a role in supporting education and training for library and information work from its earliest days. Its activities included supporting the establishment of two regional Schools of Librarianship during the 1970s - in the West Indies and the Philippines. During the 1980s the emphasis naturally progressed to providing regional models for the development of information science programmes - in Latin America (Venezuela) and Africa (Nigeria and Ethiopia). ${ }^{\mathrm{xv}}$ Through its support for the educational work of the relevant international non-governmental professional organisations (IFLA, FID and ICA), UNESCO 
has also provided further opportunities for interchange between teachers in the field and stimuli for curricular development. ${ }^{\text {xvi }}$

However, the withdrawal of the U.S.A., Britain, and Singapore from membership of UNESCO created a major financial crisis in the organisation, and budgets were severely reduced. Within the Division of the General Information programme (P.G.I.), the budget for direct support of educational development fell from about $\$ 250,000$ p.a. to around $\$ 100,000$ p.a. Although P.G.I. has always had an additional role as a channel for the funds of other United Nations agencies which are supporting projects with an indirect involvement in professional education, the impact of the budget reductions caused a significant re-orientation of P.G.I's educational work.

UNESCO generally turned to supporting activities which did not require significant support from UNESCO funds, for example funding professorial Chairs in selected Universities, and to encouraging inter-institutional links. The guidelines for twinning of libraries, sponsored by P.G.I. and issued by I.F.L.A., may be seen in that light. ${ }^{\text {xvii }}$ They provide a valuable medium for sharing best practice in all kinds of libraries, and particularly as a component within the UNESCO university twinning programme. There was at the same time, within UNESCO, a very high interest in the developments in information technologies, and their possible impact on education $^{\text {xviii }}$. Twinning and other forms of cooperative activities would clearly be enhanced by rapid and reliable telecommunications.

\section{The establishment of SLISNET}

In the early 1990s, the need for Schools of Librarianship and Information Sciences to enhance their capabilities in the field of electronic information was made known to UNESCO in several regional meetings of Schools ${ }^{\text {xix }}$. Subsequently, in May 1995, provisional invitations to participate in the proposed Network were sent to 17 Schools of Librarianship and Information Sciences. Funding for the meeting and related development were subsequently approved for incorporation in the P.G.I. budget for 1996-1997. In December 1995, representatives of 16 Schools met in Pittsburgh at the invitation of UNESCO. ${ }^{\mathrm{xx}}$ The invited institutions represented all regions of the world, and had been selected because of their previous association with UNESCO in various international technical cooperation projects. Many were also accustomed to working together in bi-lateral projects, supported by national governments or regional aid agencies, and were assumed to have reached a level of self-reliance and academic and operational reliability. The Schools represented were:

$\begin{array}{ll}\text { Botswana } & \text { - University of Botswana, Gaborone } \\ \text { Brazil } & \text { - Universidade do Brasilia } \\ \text { Canada } & \text { - Université de Montreal } \\ \text { China } & \text { - Institute of Scientific and Technical Information of China } \\ & \text { (ISTIC), Beijing } \\ \text { Denmark } & \text { - Danmarks Biblioteksskole, Copenhagen } \\ \text { Ethiopia } & \text { - University of Addis Ababa } \\ \text { France } & \text { - Ecole Nationale Superieure des Sciences de l'Information et des } \\ \text { Great Britain } & \text { Bibliotheques (ENSSIB), Villeurbanne } \\ \text { India } & \text { - The Robert Gordon University, Aberdeen }\end{array}$


Jamaica

Morocco

Nigeria

Philippines

Slovakia

U.S.A.

Venezuela
Statistical Institute, Bangalore

- University of the West Indies, Kingston

- Ecole des Sciences de l'Information (ESI), Rabat

- African Regional Centre for Information Science, University of Ibadan

- University of the Philippines, Quezon City

- Comenius University, Bratislava

- University of Pittsburgh

- Universidad Simon Bolivar, Caracas

At the meeting, it was agreed to establish an experimental, international network of Schools of Librarianship and Information Sciences - SLISNET - with the following objectives:

- To establish North-South and South-South co-operative links among schools of library and information sciences, to address needs and demands of the changing and increasingly complex information environment

- To reinforce the educational capabilities of each institution in relation to teaching, learning, research, publishing and service capabilities

- To strengthen the role of the schools of library and information sciences in the Information Society

- To experiment with the new communication and cooperative opportunities offered by the Internet

The 16 institutions attending the meeting and agreeing to participate were each committed to:

- designating a contact person to serve as a focal point for SLISNET

- responding promptly to all requests for cooperation received from member institutions

- making proposals for activities to be developed in cooperation with other SLISNET members on a voluntary basis, such as: organisation of courses, production, dissemination and use of educational material, preparation and/or revision of curricula, etc.

- cooperating in research activities such as joint research and development projects, dissemination of research results and discussion groups on specific research issues.

- implementing activities identified specifically for the pilot project

P.G.I's role was to be largely that of the coordinating focal point, getting things started and securing money for initiating operations. The initiative for activities is intended to be shared by participating institutions. A Steering committee was to be established by UNESCO with the following functions: coordination, fund-raising, dissemination of information about SLISNET, and progress evaluation. Changes in the direction and funding of P.G.I. appear to have terminated that part of the project.

\section{Connectivity}

Three Schools which were invited to join the Network had no Internet connection at the time of the meeting in Pittsburgh, but it was recognised that this would be funded by UNESCO as part of the project. However, it was almost 18 months before the links to all three (in Botswana, Jamaica, and Nigeria) were completed. In total some $\$ 20,000$ of P.G.I. funds was allocated to connect the three Schools. In each case, significant difficulties were encountered. 
The experience of the University of Botswana Department of Library and Information Studies typifies the frustrations encountered in these three partners in the developing countries in accessing the Internet. The equipment necessary was identified by UNESCO in May 1996, but the actual purchases were not specified by the Department until January 1997 after joint consideration of what might actually be purchased locally with the limited available funds available. Subsequently, the project was further delayed by approximately three and half months. Internet connectivity for the entire University was only achieved in February 1997. Originally facilities were centralised and access was very limited. The University embarked on a massive project to upgrade the infrastructure to support increased networking capacity, but cabling facilities for the Department of Library and Information Studies only permitted access to the Internet in May. Now individual offices are being linked to the campus network and access to and use of facilities is more widespread. In any event, the procedure of acquiring hardware and software from the local vendor took rather long because of delays in licensing educational software from the USA. The order was finally placed in April 1997, but delivery was only made in June and installation \& testing started in July. A Department Home page has been established to demonstrate the functioning of the system. ${ }^{\mathrm{xxi}}$ It should now be possible to take all DLIS staff and students on board to participate in the SLISNET initiatives. ${ }^{\text {xii }}$

\section{Activities to date}

During the Pittsburgh meeting, participants identified a range of potentially useful activities, and agreement was reached on those for which a particular participant would be responsible. A number of these projects have been successfully completed or made substantial progress.

A Website has been established at ENSSIB which includes a profile of SLISNET participating institutions and links to participants' Homepages (where these exist). ${ }^{\text {xiii }}$ This became open to members in February 1997, and was more widely publicised by ENSSIB at its stand in the IFLA Conference exhibition in Copenhagen in August 1997.

In addition, a listserv for a discussion group is administered by Comenius University. The discussion list has been used only infrequently, as might be expected in a closed list serving only 16 institutions and about 200 people. Much of the discussion has been prompted by UNESCO Headquarters, reporting on developments in the network, or seeking information about progress. In addition there has been a discussion between some participants about admitting students as users of the list, and this proposal is to be implemented in September 1997. The participation of students in discussion groups is indeed a welcome idea, but students in developing countries may not be able to participate fully because the availability and use of information technology is not as widespread. Consulting the students to seek their views as to which topic they are committed to put time to discuss may, however, draw quite a range of topics because of the different contexts students are in. Moreover, whilst English tends to be a predominant language of communication in Librarianship and Information Science, students may not be confident users of the language. It may, therefore, be necessary to consider running a number of smaller parallel discussions within the main discussion. ${ }^{\text {xxiv }}$

The Robert Gordon University has established a Web page identifying material that is available on the Web about the Internet and its use, providing, in effect, both a distance learning course for SLISNET members and a source of teaching materials. ${ }^{\mathrm{xxv}}$ Another page currently under construction will provide a similar series of links to electronic material on 
research methodologies in library and information sciences, as well as some original material converted to electronic format.

At the Universite de Montreal, a feasibility study on the concept of the virtual library has been conducted as a basis of a pilot project to be implemented by 4 schools ( 2 from developed and 2 from developing countries). The report on this project may be posted on the SLISNET Website in the near future, and funding is now being sought for the project.

The University of Botswana, Department of Library and Information Studies accepted responsibility for implementing a collaborative project leading to the publication of a collection of case studies on the impact of information technology on society. The Department has now embarked on this project. A brief introduction/theme paper has been written, and will shortly be circulated to SLISNET members. The purpose of this introduction is to stimulate discussions. It is hoped that contributions from various participants will lead to the development of guidelines for the research project, and the research can then be set in motion.

\section{Ongoing projects}

Other projects expected to come to fruition during the first three years of SLISNET's existence include:

- Developing an inventory of distance education programs in library and information science (U.W.I., Jamaica)

- Identifying potential information-related research and development opportunities through interface with other networks (ENSSIB)

- Initiating the development of an appropriate response from SLISNET participants, to the needs and demands identified in the external environment, through the establishment of research projects, consultancy, and publication (ENSSIB)

- Coordinating and disseminating information about conferences and workshops organised by SLISNET participants (either individually or collaboratively) in their institutions, and others addressed to the profession generally on topics of relevance to SLISNET (Danmarks Biblioteksskole)

- Identifying and compiling a list of Library and Information Sciences information resources available in electronic form (DRTC, Bangalore)

- Identifying and contacting producers, vendors and potential donors about electronic teaching materials which are freely available (Universite de Montreal, and the Robert Gordon University)

- Developing a proposal for funding a feasibility study for the establishment of a full text CD ROM Journal Services in LIS; carrying out the feasibility study; and submitting proposal to donor to distribute the CD Service (and related equipment if necessary) to SLISNET participants and other schools of LIS. (The Robert Gordon University, Aberdeen.)

In addition, participants were exhorted to facilitate the conventional activities of international cooperative programmes:

- sharing teaching/classroom materials in electronic form

- facilitating teaching staff exchanges (e.g. Fulbright, visiting lecturers, etc.);

- renewing knowledge and expertise of teaching staff using SLISNET; 
- assisting with peer review process (e.g. journal articles).

- facilitating exchange of students for study, fieldwork, etc.;

- sharing information about support for these activities.

Finally, it should be noted that, in keeping with SLISNET's implicit objective of raising the institutional profile of Schools in a rapidly changing discipline, it was recommended that deans/directors, etc. should seek to engage in the development of I/T policy within their parent institution and nationally.

\section{International activities}

In Asia, the P.G.I. Regional Office organised a meeting in March 1997 on 'planning human resources development for information societies'. In Latin America, the P.G.I. Regional Office has Been trying to develop collaboration between Schools of Librarianship, organising several meetings to that purpose. In collaboration with IFLA and FID, the author has secured funding from the UNESCO Participation Programme for a meeting in Latin America to examine management education (including Information Technology management), which will provide an opportunity to bring together representatives of the SLISNET partners in the region.

The Robert Gordon University and Danmarks Biblioteksskole are also partners in a project which received initial funding from the European Commission ALFA programme in 1997 to set up a research network with Latin American partners. None of the prospective Latin American partners are currently in SLISNET. However, a visit to Latin America provided the author with an opportunity for a brief and relatively inexpensive diversion to Brasilia to develop a greater understanding of the local context and strengthen the personal contact.

\section{Bi-lateral activities}

The network was not intended to replace bilateral agreements but to help initiate such agreements on academic linkages and staff exchanges. Visiting scholarships and academic collaboration in research and teaching between institutions clearly need funding outwith the scope of the original UNESCO concept for SLISNET. There has, however, already been at least one example of such a development.

Dr. Isola Ajiferuke from the African Regional Centre for Information Science spent a 3month sabbatical at the Robert Gordon University in early 1997, supported by a Fellowship from the Association of Commonwealth Universities. He undertook preparatory work for new courses on the Internet and World Wide Web, and for a project on the impact of Information Technology on SMEs in Nigeria, for which he has some local funding. This project is of particular interest to some of the Robert Gordon University staff who are researching in the area of information impact. The European Commission programme INCODC (International Cooperation with Developing Countries) may provide the vehicle to continue that link. A requirement of INCO-DC is that each project should have partners in more than one developing country, so it might be appropriate to try to draw in other SLISNET partners, particularly the School in Botswana which is coordinating the publication of case studies in this area. 


\section{Institutional initiatives}

A number of developments are also taking place in the individual partner Schools which confirm progress towards SLISNET's underlying aim of encouraging the development of the kind of professionals required in the 'Information Society'. At Universidade do Brasilia, the Department is somewhat constrained by an outline curriculum prescribed by Federal legislation, which is a requirement for jobs which specify a qualification in librarianship. The present government seems, however, to be more flexible that its predecessors and some greater deviation from legal norms appears possible. Against this background the University has been persuaded to permit the Department to offer a new course in "databases", i.e. electronic information sources. This will commence in August 1997, and will be taught in the evenings. ${ }^{\text {xxvi }}$

At The Robert Gordon University, a new full-time Masters Degree programme in Electronic Information Management, developed in collaboration with the Schools of Electronic and Electrical Engineering and Computer and Mathematical Sciences, was established in 1997 in direct response to demands from employers in all sectors. ${ }^{\text {xxvii }}$

\section{Prognosis}

The representatives who attended the Pittsburgh meeting recommended that the project should be supported by UNESCO for at least six years, with an interim evaluation after three years and an overall evaluation after six years. In that context it would be both premature and presumptuous to attempt an evaluation after less than two years. What follows is, therefore, more a discussion of SLISNET's potential than criticism of its current reality.

Web pages are notoriously passive information providers, and the systems for counting 'hits' are not necessarily accurate. In any case they provide a misleading picture since they do not provide a qualitative measure, indicating the way in which the information gained from them has been used. Moreover, most of the Schools of Librarianship which have created their own Homepages have supplemented them with useful links - to libraries and to other Schools' pages. Much of the information which is accessible through the SLISNET Web site is thus accessible through other channels. Where the SLISNET Web site usefully supplements sites such as the 'World list of Library Schools' ${ }^{\text {xxviii }}$ is in its capacity to host information for those Schools not yet well enough equipped to host their own Homepage.

There appears to be some benefit in expanding the coverage of the SLISNET Web site to host information from Schools which do not have their own Home page, and to create links to those which do have them. UNESCO has previously supported the development of international directories of Schools of Librarianship ${ }^{\text {xxix }}$, and an electronic directory seems a natural development of this work. However, some prior work must go into the development of a search system which will enable information about specific aspects of School's work to be retrieved efficiently. Some guidelines on the minimum information which might be considered useful would not be difficult to promulgate. They already exist, by implication, in the structure of the latest print-based directory. 
There are relatively few discussion lists about education for librarianship and information sciences. The list operated by BAILER serves mainly as a vehicle for the Schools to announce information of a self-promotional nature, frequently at the same time as it is announced on other discussion lists in Britain and abroad. The lists in the U.S.A. are equally inert. JESSE, the list for library and information science educators is regularly dormant, as is ELEASAI, the list for researchers. VIFLIS, the list for all participants in LIS education, has recently been closed for lack of use. Indeed, all three listservs have carried few requests and little debate about teaching content and methods. They appear to have been used rather more for transmitting announcements of new staff, conferences, or courses. The only continually lively discussion list is CRISTAL-ED, a list administered by the University of Michigan as part of a Kellogg Foundation supported project to renew the curriculum. The significant features of this list are the regular change of volunteer guest editors, each provoking discussion on a specific project, and the substantial contributions from the practitioner community. CRISTAL-ED may cease when the grant ceases, and is in any case dominated by North-North dialogue.

Perhaps there are some lessons for SLISNET in the way in which CRISTAL-ED operates? There certainly appear to be some potential benefits in opening the SLISNET discussion list not only to all the other Schools in the world, but also to the practitioner community. There are numerous well established lists for practitioners, particularly in the industrialised countries $^{\mathrm{xxx}}$, and the educators follow those relevant to their teaching, as they help point to issues of current interest to the practitioner community. They can and do occasionally intervene in the debate, but the discussion rarely touches on the selection of appropriate content and methods for teaching about the issue. All too often, whilst the practitioners feel shut out from the debate about professional education, at the same time the educators feel that they are misunderstood by a practitioner community which is not, in its entirety, maintaining the same close relationship with the leading edge of professional developments and practice as the Schools have to do. If, however, the SLISNET discussion list is opened to practitioners to improve this dialogue, a necessary concomitant is the appointment of regular guest editors to provoke discussion on specific topics. At the very least, one would hope that a discussion between the Schools on a North-South and South-South basis could be stimulated.

Moyo has suggested some specific activities which SLISNET might foster could include exchange of information on curricula/course offerings, program details, such as fees, entry requirements, number of credit hours/units, language of instruction, duration of program, sharing of educational material etc. ${ }^{\mathrm{xxxi}}$ Notwithstanding the repeated requests over the years for a resource centre for teaching materials for use in Schools of Librarianship, teachers appear to show little enthusiasm for asking their peers for advice on how to approach the teaching of a particular topic. Indeed, the professional literature for teachers of library and information sciences is not overwhelmed with papers about how the teaching of specific subjects is developing. ${ }^{\text {xxii }}$

Moyo has also suggested that the network might lead to better communication with peers, for example one to one networking of people involved in similar projects, offering an open exchange of personal and professional information. One might speculate on the selfcontained nature of teaching as a profession as a factor inhibiting the development of this aspect of the network. The teacher is accustomed to being alone in the classroom, solely dependent on his/her own capabilities. 
Much of the potential collaborative effort is, moreover, constrained by what can be made publicly available. Higher education is becoming a competitive business in the industrialised countries, as institutional income is increasingly driven by student recruitment. In a rapidly changing field, there will inevitably be some reluctance to reveal details of innovative new courses to potential competitors, and more traditional means of information transfer offer a possibly more acceptable means of selectively disseminating ideas to network partners.

Nonetheless, focusing on the subject interests of individual teachers could be a significant factor in encouraging use of the Web site and the discussion list. Links could be established not only to other UNESCO digital projects in the LIS field, such as the 'Memory of the World' programme ${ }^{\text {xxxiii }}$, INFOETHICS ${ }^{\text {xxxiv }}$, and the Inter-governmental Informatics Programme ${ }^{\mathrm{xxxv}}$, but also to the ongoing research projects in partner institutions and other Schools of Librarianship and Information Sciences. Another valuable addition would be the facility to access teaching material held in electronic formats. These initiatives would have the added advantage of enhancing the scope of SLISNET, which at present appears to have an introspective character, to acknowledge the engagement of the Schools in the broad spectrum of professional activities connected with using this new medium to get information into the public domain.

While institutions are the members of the network, it will always rely on interested and committed individuals who will be responsible for the real work related to the institutions' participation. And, as the American management 'guru' Tom Peters has observed:

"There is no requirement that the cost of excellence is suffering. But there is also no guarantee that the process will be graced by a personal and professional 'balance', where things work out nicely on both fronts... The price of excellence is time, energy, attention and focus..." xxxvi

Against this, one has to keep in mind that participation in a network is a "give-and-take" operation: each member will contribute if he receives something in return; this applies both to individuals and institutions participating in the network. At the institutional level, it perhaps requires some acknowledgement of the individual workload which might be involved in active participation. However, even within the participating Schools, there appears to be the lack of awareness of SLISNET. In many, including regrettably the author's own School, the existence and role of SLISNET is not widely known and appreciated beyond the small circle of representatives who attended the founding meeting in Pittsburgh and those colleagues who were subsequently designated as SLISNET Coordinators. It is by no means clear that the information about the various Web sites, or the messages on the discussion list have been disseminated within the partner institutions.

A major inhibiting factor in the development of collaborative activity across the networks appears to be the way in which individual institutions have to pay for their use of the Internet. In Britain, the overall cost of the network infrastructure and use is borne centrally, by the Computer Services Department of Universities and by the Joint Information Systems Committee of the Higher Education Funding Councils. The user is thus sheltered from the costs of using a system based on an ultra-modern telecommunications system. The same cannot be said to be true of other countries. Clearly, the level of interest stimulated by the network's activities and the benefit from participation must be sufficient to justify not only the individual's time but also the cost to the institution. At this stage of the network's development it is too soon to evaluate this. 
There are major changes taking place in telecommunications systems, which will facilitate the rapid transmission of text and images. ${ }^{\text {xxxvii }}$ These will make the Internet a practicable medium for video-conferencing. Whether this will facilitate use of the SLISNET system to share teaching or simply to overcome the inhibitions of using it to contact colleagues who are unknown on a personal basis remains to be seen. In any event, the costs of the system (particularly the international telecommunications charges) may well remain beyond the capabilities of some of the Schools in the developing countries, simply because of the economic conditions which prevail.

Providing adequate resources to manage the network will be a particularly important factor during the early phase of development to maintain the continued interest of the members and the dynamics of the network. At around the time that SLISNET was being established, discussions were taking place within UNESCO about the future direction of P.G.I., and subsequently the Division of the General Information Programme was amalgamated with the Division of Informatics. The Division of Informatics, like P.G.I. a part of the Communication, Information and Informatics Sector, was the leading agency in UNESCO's attempts to encourage international and particularly inter-governmental networking of information. In the context of the amalgamation of these Divisions, one might have expected the support for SLISNET to be enhanced.

Paradoxically, however, UNESCO's next planning period was marked by the removal from the draft budget of the funding for a meeting of the SLISNET coordinators and Schools' Directors to discuss how to make use of the Web site, how to develop cooperation among SLISNET members, and how to pursue the virtual library component.. In one sense, the removal of this funding will provide a significant test for the ideas underlying the Network. In another sense, it might stimulate the search for alternative funding sources which it was always acknowledged would have to be secured to assure the long-term future of this project. Nonetheless, one cannot but conclude that the concept has not yet been developed sufficiently to permit a proper evaluation, and that to explore the potential some additional pump-priming is necessary, in terms of both UNESCO funding and effort from the partner institutions.

"A passion for excellence means thinking big and starting small: excellence happens when high purpose and intense pragmatism meet."

\section{AUTHOR}

Ian Johnson has been Head of the School of Information and Media at The Robert Gordon University, Aberdeen, Scotland since 1989. Previously he was in charge of industry liaison and continuing education programmes at the College of Librarianship Wales; Assistant to the British Government's Advisers on library matters; and an operational manager in public libraries. He was Chairman of the IFLA Section on Education and Training from 1991 to 1993, and Chairman of the Professional Board of IFLA from 1993 to 1995. From 1993 to 1995 he was also Chairman of the (British) Library Association's Personnel, Training and Education Group. He is currently a member of the Council of The Library Association, and of the Editorial Board of Education for Information; and Chairman of the Heads of Schools and Departments Committee of BAILER: the British Association for Information and Library Education and Research. 
(WWW Homepage URL: http://www.rgu.ac.uk/schools/sim/staff/imj/imj/htm)

September, 1997

\section{REFERENCES}

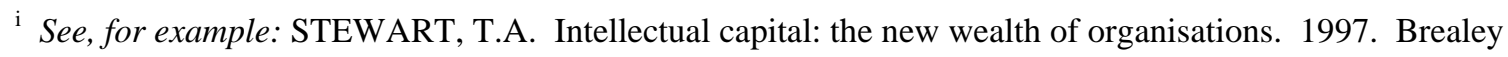
Publishing.

ii WILLIAMS, D.A. and FARMER, J.C. Future needs and skills. in A konyvtaros es informacios szakemberkepzes megujitasa - Renewing the education and training of librarians and information professionals: proceedings of the closing conference of the LISTEN TEMPUS JEP (1994-97); Berzsenyi College, Szombathely, Hungary, 25th to 27th June 1997. 1997. Hungary: Szombathely, Berzsenyi College. pp.101-110.

iii LARGE, J.A. Library education for libraries without walls $\underline{i n}$ Library and Information Science - parameters and perspectives (Essays in honour of Prof. P.B. Mangla); edited by R.G. Prasher. 1997. India, New Delhi: Concept Publishing Company. 2 vols. Vol.1 (Library and Information Science: basic), pp. 176-185.

iv JOHNSON, I.M. The development of education and research for the electronic library - opportunities and challenges: paper presented to the Section on Education and Training during the I.F.L.A. Conference, Copenhagen, August 1997. (I.F.L.A. Conference papers ref. 107-SET-3-E)

$\checkmark$ JOHNSON, I.M. Recent trends in cooperation between schools of librarianship and information studies $\underline{i n}$ Library and Information Science - parameters and perspectives (Essays in honour of Prof. P.B. Mangla); edited by R.G. Prasher. 1997. India, New Delhi: Concept Publishing Company. 2 vols. Vol.1 (Library and Information Science: basic), pp. 75-80.

vi HARBO, O. The Nordic network. Education for Information, 12 (2), June 1994, 271-272.

vii HARBO, O. EUCLID. Education for library and information services: Australia, 11 (3), November 1994, 23-26.

viii JOHNSON, I.M. Recent trends in cooperation between schools of librarianship and information studies $\underline{i n}$ Library and Information Science - parameters and perspectives (Essays in honour of Prof. P.B. Mangla); edited by R.G. Prasher. 1997. India, New Delhi: Concept Publishing Company. 2 vols. Vol.1 (Library and Information Science: basic), pp. 75-80..

ix COOMBES, D. Spreading the word: the library work of the British Council. 1988. London: Mansell.

${ }^{x}$ HAWLEY COMMITTEE. Information as an asset: the board agenda. 1996. London: KPMG IMPACT.

xi LAU, J. A study of the socio-economic factors influencing information development in low, middle, and highly developed countries. 1988. University of Sheffield, PhD Thesis.

xii MENOU, M.J., Editor. Measuring the impact of information on development. 1993. Canada, Ottawa: International Development Research Centre.

xiii JOHNSON, I.M. Staff development: a Western perspective. in A konyvtaros es informacios szakemberkepzes megujitasa - Renewing the education and training of librarians and information professionals: proceedings of the closing conference of the LISTEN TEMPUS Joint European Project, Berzsenyi College, Szombathely, Hungary, June, 1997. Hungary, Szombathely: Berzsenyi College, 1997. pp. 91-100.

xiv See, for example, OSEMAN, R. Conferences and their literature: a question of value. 1989. London: Library Association Publishing Ltd.

${ }^{x v}$ PARKER, J.S. UNESCO and library development planning. 1984. London: Library Association.

${ }^{x v i}$ JOHNSON, I.M. Editor. Harmonisation of education and training programmes for library, information and archival personnel: proceedings of an international colloquium, London, August 9 - 15, 1987. 1989. Munich: K.G. Saur. (2 vols.)

xvii DOYLE, R.P., and SCARRY, P. Guidelines on library twinning. 1994. Paris: UNESCO

xviii TOCATLIAN, J. UNESCO and the Information Superhighway. Information Development, 11 (3), September 1995, 146-151.

xix for example:

Meeting of experts on the education of information specialists in the Arab region: Ecole des Sciences de l’Information, Rabat, Maroc (10-13 May 1993). Final Report. Paris: UNESCO. (ref. PGI-93/WS/13)

AND

Workshop on education and training of information specialists in Eastern Europe and the Commonwealth of Independent States, Bratislava, Slovakia, November 1994. Final report. Paris: UNESCO, 1995. (ref. CII95/WS/10) 
${ }^{\mathrm{xx}}$ UNESCO. Workshop on the establishment of the international network of Schools of Library and Information Sciences (SLISNET), Pittsburgh, School of Library and Information Science, University of Pittsburgh, December 4 - 7, 1995: Final report. 1995. Paris: UNESCO. (CII/95/WS/12)

${ }_{\text {xxi }}$ Currently, a response is only available using the IP address: http://168.167.12.19.

xxii Information from Lesley Moyo, University of Botswana DLIS SLISNET Coordinator, August 1997.

xxiii URL - http://enssibhp.enssib.fr/SLISNET/

${ }^{x x i v}$ Information from Lesley Moyo, University of Botswana DLIS SLISNET Coordinator, June 1997

xxv URL - http://www.rgu.ac.uk/schools/sim/netlearn/callist.htm

${ }^{\text {xxvi }}$ Reported to the author during a visit to Brasilia, July 1997.

xxvii URL - http://www.rgu.ac.uk/schools/sim/courses/

xxviii URL - http://www.sheff.ac.uk/ is/lecturer/tom2a.htm\#den

${ }_{\text {xxix }}$ FANG, J.R. and others. World Guide to Library, Archive and Information Science Education. 2nd edition. 1995. Munich: K.G. Saur. (IFLA Publications 72/73)

${ }^{\mathrm{xxx}}$ See, for example the list provided in: BAILEY, C.W. Library oriented lists and electronic serials. ITs News, 28, November 1993, 36-41.

xxxi MOYO, L.M. International network of Schools of Library and Information Sciences (SLISNET) - report on activities in Botswana: paper presented at the Southern African Computer Lecturers' Association Annual Conference (SACLA '97), Wilderness, South Africa, June 22 - 24, 1997. [Typescript, 10pp.]

xxxii HEAD, M.C., and MARCELLA, R.C. Teaching 'reference work' in Aberdeen: a personal perspective. Education for Information, 13 (1), 1995, 67-71.

xxxiii AZIZ, Abdelaziz. Memory of the World: preserving the documentary heritage. IFLA Journal, 21 (3), 1995, 169-174.

xxxiv INFOETHICS: first international congress on ethical, legal and societal aspects of digital information, Monte Carlo, Principality of Monaco, 10-12 March 1997. UNISIST Newsletter, 25 (1), 1997, 20-22

xxxv DANZIN, A. The Intergovernmental Informatics programme. Impact of Science on Society, 146, 1987, 109-113.

xxxvi PETERS, T., and AUSTIN, N. A passion for excellence: the leadership difference. 1985 London: Collins.

xxxvii MURDOCH, J.W., and others . Developments in communications technology: an introduction for the non-technical reader. Audiovisual librarian: multimedia information, 23 (2), May 1997, 112-117.

xxxviii PETERS, T., and AUSTIN, N. A passion for excellence: the leadership difference. 1985. London: Collins. 